\title{
PENGEMBANGAN LEMBAR KERJA SISWA (LKS) MATEMATIKA LAMBANG BILANGAN ROMAWI MELALUI STRATEGI TANDUR
}

\author{
Desi Setiyadi \\ desisetiyadi12@gmail.com,
}

\begin{abstract}
This research and development on the Mathematics students' worksheet (LKS) on the Cardinal Symbol through TANDUR Strategy. 1) the factual condition in SD on the use of worksheets in teaching-learning, 2) the development of the mathematics LKS on the Cardinal Symbol through TANDUR Strategy, 3) the validity of the mathematics LKS on the Cardinal Symbol through TANDUR Strategy for fourth grade in elementary school 4) the effect of mathematics worksheet on TANDUR Strategy on the students' mathematics learning achievement on Cardinal Numbers, 5) the teachers evaluation of mathematics worksheet on the Cardinal Symbol through TANDUR Strategy for the fourth graders, 6) the students respond to mathematics LKS on the Cardinal Symbol through TANDUR Strategy in for the fourth graders in elementary school. The population used was 24 students from the fourth graders of an elementary school in UPK Kebasen. The technique for collecting data was by test and non-test, namely by pretest-posttest, and expert validation, teacher evaluation, student response questionnaire. The research was that: 1) the development of mathematics worksheet on the Cardinal Symbol through TANDUR Strategy was an alternative to solving the problems, 2) the score of validity of mathematics worksheet on the Cardinal Symbol through TANDUR Strategy from the three validators was very valid, 3) There was an effect on mathematics worksheet on the Cardinal Symbol through TANDUR Strategy toward the students' mathematics learning audit on Cardinal Numbers, 4) Teachers evaluation of mathematics worksheet on the Cardinal Symbol through TANDUR Strategy for fourth graders was very good, and 5) The student response from mathematics worksheet on the Cardinal Symbol through TANDUR Strategy was agreed very much.
\end{abstract}

Key words: Students' worksheet, Mathematics, TANDUR Strategy.

Abstrak. Penelitian dan pengembangan tentang pengembangan lembar kerja siswa (LKS) matematika lambang bilangan romawi melalui strategi TANDUR. Tujuan penelitian untuk mengetahui : 1) kondisi faktual di SD penggunaan LKS dalam pembelajaran, 2) pengembangan LKS matematika lambang bilangan romawi melalui strategi TANDUR, 3) kevalidan pengembangan LKS matematika lambang bilangan romawi melalui strategi TANDUR kelas IV di SD, 4) pengaruh LKS matematika lambang bilangan romawi melalui strategi TANDUR terhadap prestasi belajar matematika lambang bilangan romawi, 5) penilaian guru terhadap LKS matematika lambang bilangan romawi melalui strategi TANDUR kelas IV di SD, 6) respon siswa terhadap LKS matematika melalui strategi TANDUR kelas IV di SD. Populasi yang digunakan sebanyak 24 siswa kelas IV SD di UPK Kebasen. Teknik pengumpulan data menggunakan tes dan non tes yaitu pre test, post test dan validasi ahli, penilaian guru, angket respon siswa. Analisis data menggunakan uji hipotesis one sampel $t$ test. Hasil penelitian menunjukkan bahwa 1) kondisi faktual di SD penggunaan LKS terdapat kelemahan, 2) pengembangan LKS matematika lambang bilangan romawi melalui strategi TANDUR merupakan salah satu alternatif memecahkan masalah, 3) LKS matematika lambang bilangan romawi melalui strategi TANDUR berpengaruh terhadap prestasi belajar matematika lambang bilangan romawi, 5) penilaian guru memperoleh skor 
4,834 dan dinyatakan sangat baik, 6) respon siswa baik dengan presentase 95,83\% kategori sangat setuju.

\section{Kata kunci : lembar kerja siswa, matematika, strategi TANDUR}

\section{PENDAHULUAN}

Pembelajaran merupakan kegiatan yang dapat menumbuhkan pemahaman, kreativitas, keaktifan, daya pikir, potensi, dan minat siswa. Kegiatan pembelajaran ditujukan kepada kegiatan yang mendorong siswa belajar aktif baik secara fisik, sosial maupun psikis. Proses untuk memahami konsep, komunikasi dua arah secara timbal balik sangat diharapkan dalam proses belajar mengajar demi terciptanya tujuan pembelajaran yang optimal apabila fasilitator (guru) mempunyai kemampuan untuk menciptakan situasi belajar yang melibatkan siswa secara aktif dan membangun motivasi siswa.

Keberadaan LKS di sekolah dasar (SD) sering digunakan guru untuk membantu proses pembelajaran. Contohnya saat guru tidak hadir di kelas, siswa diberi tugas untuk mengerjakan LKS. Hasil wawancara yang dilakukan bersama guru kelas IV SD menghasilkan beberapa pernyataan tentang LKS yaitu 1) Materi yang disajikan terlalu sedikit sehingga membuat siswa kebingungan, 2) Kalimat yang digunakan cukup baik, 3) Bentuk soal tidak mengalami perubahan pada setiap tahunnya (monoton), 4) Tidak ada kalimat motivasi siswa, 5) Pengemasan LKS yang tidak berwarna membuat siswa kurang tertarik khususnya mata pelajaran matematika.

Hasil wawancara yang dilakukan dengan siswa kelas IV sekolah dasar sebagian besar menyatakan tentang LKS mata pelajaran matematika yang membuat pusing dan malas untuk mempelajarinya karena dipenuhi dengan angka, simbol, dan rumus. Persepsi ini telah menjadi pola pikir siswa sejak dahulu sehingga mereka malas dalam mempelajari lebih lanjut tentang angka dan simbol sampai sekarang.

Salah satu bab yang terdapat banyak angka dan simbol matematika di kelas IV KTSP 2006 adalah lambang bilangan romawi. Bab tersebut terdapat pada SK 7. Menggunakan lambang bilangan romawi, KD 7.1 Mengenal lambang bilangan romawi, 7.2 Menyatakan bilangan cacah sebagai bilangan romawi dan sebaliknya.

Masalah yang timbul di atas, dapat dijadikan sebagai acuan untuk melakukan sebuah penelitian pengembangan lembar kerja siswa (LKS) matematika melalui strategi TANDUR. Strategi ini diadopsi dari model quantum teaching. Istilah TANDUR merupakan singkatan dari $\mathrm{T}=$ Tumbuhkan,

$\mathrm{A}=$ Alami, $\mathrm{N}=$ Namai, $\mathrm{D}=$ Demonstrasikan, $\mathrm{U}=$ Ulangi, dan $\mathrm{R}=$ Rayakan. Penelitian diarahkan untuk melakukan pengembangan LKS matematika lambang bilangan romawi melalui strategi TANDUR di kelas IV SD. Penelitian dilakukan berawal dari kondisi faktual di SD dalam menggunakan LKS, pengembangan LKS, validasi ahli, uji coba, penilaian guru, dan angket respon siswa sebagai pengguna produk secara langsung.

LKS merupakan salah satu bahan ajar yang dapat digunakan dalam pembelajaran, menurut Prastowo (2014: 204) LKS merupakan suatu bahan ajar cetak berupa lembar-lembar kertas yang berisi materi, ringkasan, dan petunjukpetunjuk pelaksanaan tugas pembelajaran yang harus dikerjakan oleh siswa, yang mengacu pada kompetensi dasar yang harus dicapai. Menurut Trianto (2009: 223) menyatakan LKS memuat sekumpulan kerja mendasar yang harus dilakukan oleh siswa untuk memaksimalkan pemahaman dalam upaya pembentukan kemampuan dasar sesuai indikator pencapaian hasil belajar yang harus ditempuh.

Mata pelajaran matematika adalah salah satu mata pelajaran yang dapat dibuat menjadi LKS. Menurut Hariwijaya (2009: 29) matematika secara umum didefinisikan sebagai bidang ilmu yang mempelajari 
pola dari struktur, perubahan dan ruang, maka secara informal dapat pula disebut sebagai ilmu tentang bilangan dan angka dalam pandangan formalis, matematika adalah penelaahan struktur abstrak yang didefinisikan secara aksioma dengan menggunakan logika simbol dan notasi.

Materi yang terkandung dalam mata pelajaran matematika di kelas IV semester II salah satunya adalah lambang bilangan romawi. Materi ini dibagi menjadi dua pokok bahasan yaitu mengenal lambang bilangan romawi dan menulis lambang bilangan romawi. Bilangan dasar romawi terdapat tujuh buah yaitu I, V, X, L, C, D, dan $\mathrm{M}$, dan menulis lambang bilangan romawi yang lain dengan cara menggabungkan atau mempadukan setiap bilangan dasar romawi.

Penyampaian materi lambang bilangan romawi dapat menggunakan strategi TANDUR yang diadopsi dari kerangka rancangan quantum teaching yang mempunyai arti $\mathrm{T}=$ Tumbuhkan, $\mathrm{A}=$ Alami, $\mathrm{N}=$ Namai, $\mathrm{D}=$ Demonstrasikan, $\mathrm{U}=$ Ulangi, dan $\mathrm{R}=$ Rayakan. Menurut Deporter, dkk. (2014: 32-33) quantum teaching adalah badan ilmu pengetahuan dan metodologi yang digunakan dalam rancangan, penyajian, dan fasilitasi SuperCamp.

Berikut ini adalah tinjauan mengenai TANDUR dan maknanya. a) Tumbuhkan mempunyai makna tumbuhkan minat dengan memuaskan "Apakah Manfaatnya BAgiKu" (AMBAK), dan mafaatnya bagi kehidupan pelajar,

b) Alami mempunyai makna ciptakan atau datangkan pengalaman umum yang dapat dimengerti semua pelajar, c) Namai mempunyai makna sediakan kata kunci, model, rumus, strategi, sebuah "masukan" d) Demonstrasikan mempunyai makna sediakan kesempatan bagi pelajar untuk "menunjukan bahwa mereka tahu", e) Ulangi mempunyai makna tunjukan pelajar cara-cara mengulang materi dan menegaskan, "Aku tahu bahwa aku memang tahu ini”, f) Rayakan mempunyai makna pengakuan untuk menyelesaikan, partisipasi, dan pemerolehan keterampilan, dan ilmu pengetahuan. Hipotesis yang digunakan yaitu lembar kerja siswa (LKS) matematika lambang bilangan romawi melalui strategi TANDUR berpengaruh terhadap prestasi belajar lambang bilangan romawi.

\section{METODE PENELITIAN}

Jenis penelitian adalah penelitian pengembangan (research and development atau $\mathrm{R}$ dan $\mathrm{D}$ ), desain penelitian menggunakan kualitatif dan kuantitatif dengan strategi eksploratoris sekuensial. Produk yang dikembangakan berupa LKS matematika lambang bilangan romawi melalui strategi TANDUR. Pengembangan LKS dilakukan menggunakan model 4-D menurut Tiagarajan, Semmel dan Semmel (1974) yaitu define, design, develop dan dessiminate, tetapi tahapan hanya sampai di tahapan develop, karena penelitian hanya melihat pengaruh LKS terhadap prestasi belajar lambang bilangan romawi dengan berpatokan KKM sebesar 60 .

Metode pengumpulan data menggunakan tes dan non tes. Tes meliputi pre test yang digunakan untuk mengukur kemampuan awal siswa, dan post test yang digunakan untuk mengetahui kemampuan akhir setelah dilakukan eksperimen. Non test meliputi lembar validasi, lembar penilaian guru, dan angket respon siswa. Uji coba instrumen dilakukan untuk mengetahui kevalidan instrumen yang digunakan dalam penelitian. Perhitungan validasi menggunakan alat bantu yaitu anates dengan memperhitungkan validasi butir soal, reliabilitas, tingkat kesukaran dan daya pembeda.

\section{HASIL DAN PEMBAHASAN}

Pemerolehan data kondisi faktual di SD dalam penggunaan LKS selama ini terdapat kelemahan yang membuat siswa tidak bisa berpikir aktif dan kreatif dalam 
pembelajaran. Kondisi yang ada disebabkan salah satunya LKS yang cukup sulit untuk dipelajari dalam belajar mandiri oleh siswa yaitu LKS matematika.

Berdasarkan hasil wawancara dengan guru kelas tentang LKS matematika yang digunakan terdapat berbagai kelemahan yaitu : a) Materi yang disajikan terlalu ringkas, sehingga siswa masih merasa kebingungan. Hal ini disebabkan SK KD pada materi hanya mencakup dua pokok bahasan, b) Bentuk soal monoton atau tidak ada perubahan pada setiap tahunnya. Perbandingan desain LKS pada setiap tahunnya tidak mengalami perubahan, sehingga membutuhkan sebuah pengembangan dan pembaharuan informasi, c) Tidak ada kalimat motivasi siswa. Bentuk kalimat yang belum mengajak siswa untuk berpikir aktif dan kreatif sehingga siswa malas untuk mempelajari LKS secara mandiri, d) Tidak ada ruang kosong yang dapat digunakan siswa untuk menulis atau menggambar di LKS. Desain LKS yang penuh dengan tulisan akan menyebabkan siswa tidak bisa memfokuskan perhatian, mengekspresikan emosi saat pembelajaran, seperti menggambar, coret menyoret, dan hasil perhitungan, e) Pengemasan LKS yang tidak berwarna membuat siswa kurang tertarik khususnya mata pelajaran matematika.

Masalah yang timbul di atas, dapat digunakan menjadi pedoman untuk melakukan sebuah pengembangan bahan ajar yaitu LKS matematika lambang bilangan romawi melalui strategi
TANDUR. Strategi yang diadopsi dari model quantum teaching yang merupakan singkatan dari $\mathrm{T}=$ Tumbuhkan, $\mathrm{A}=$ Alami, $\mathrm{N}=$ Namai, $\mathrm{D}=$ Demostrasikan, $\mathrm{U}$ = Ulangi, dan $\mathrm{R}=$ Rayakan. Langkah selajutnya dalam penelitian yaitu pengembangan LKS matematika lambang bilangan romawi melalui strategi TANDUR.

Pengembangan LKS matematika lambang bilangan romawi melalui strategi TANDUR menggunakan pengembangan model 4-D menurut Sivasailam Thiagarajan, Semmel dan Semmel (1974) yaitu define, design, develop, dan dessiminate. Penelitian dilakukan hanya sampai tahap develop karena penelitian hanya ingin melihat pengaruh produk yang dihasilkan dengan berpatokan KKM sebesar 60 .

Tahap pengembangan dilakukan untuk memperoleh draft 1. Kegiatan dimulai dari analisis awal akhir pada tahap define sampai dengan rancangan awal pada tahap design. Tahapan tersebut dapat disimpulkan tahapan pengumpulan bahan mentah sebagai pendukung terbentuknya draft 1, seperti gambar, materi, dan animasi. Bahan mentah dipilih untuk menentukan bahan yang digunakan dalam produk yang dikembangkan.

Validasi terhadap LKS matematika dilakukan oleh tiga orang ahli yang bertujuan memberikan kritik dan saran untuk menyempurnakan produk yang dikembangkan. Hasil validasi memperoleh skor 4,258 dan dinyatakan sangat valid.

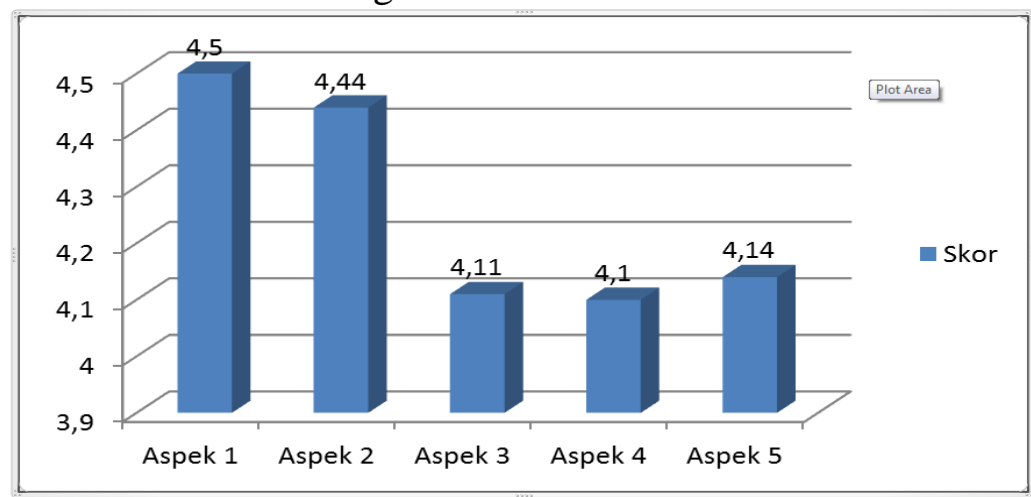

Gambar 1. Diagram Batang Validasi Ahli 
Uji t satu sampel untuk menguji $\mathrm{H}_{0}$ : $\mu=60$ atau $\mathrm{H}_{\mathrm{a}}: \mu \neq 60$ dengan $\alpha=$ 0,05 . Nilai signifikansi memperoleh 0,000 $<0,05$, maka $\mathrm{H}_{\mathrm{a}}$ diterima yang berarti terdapat pengaruh lembar kerja siswa (LKS) matematika lambang bilangan

romawi melalui strategi TANDUR terhadap prestasi belajar matematika lambang bilangan romawi dengan berpatokan nilai KKM sebesar 60 . Berikut ini hasil perhitungan one sampel $t$ test menggunakan SPSS.

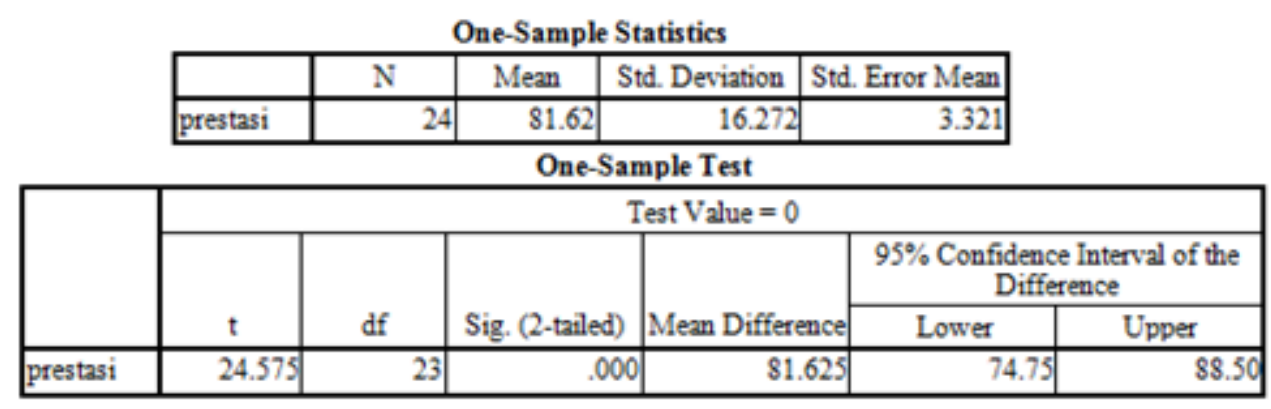

\section{Gambar 2. One Sampel T Test}

Penilaian guru dilaksanakan setelah uji pengembangan atau eksperimen telah selesai. Penilaian ini berguna sebagai data pendukung dari produk yang dikembangkan yaitu LKS sebagai pengguna produk langsung, skor rata-rata dari semua aspek sebesar 4,834, apabila dikonsultasikan dengan tabel penilaian guru dinyatakan sangat baik atau tanpa revisi.

Berdasarkan analisis respon siswa dapat disimpulkan bahwa siswa yang memilih opsi "setuju" atau "sangat setuju" sebanyak 23 siswa dan siswa yang memilih opsi "tidak setuju" sebanyak 1 siswa.

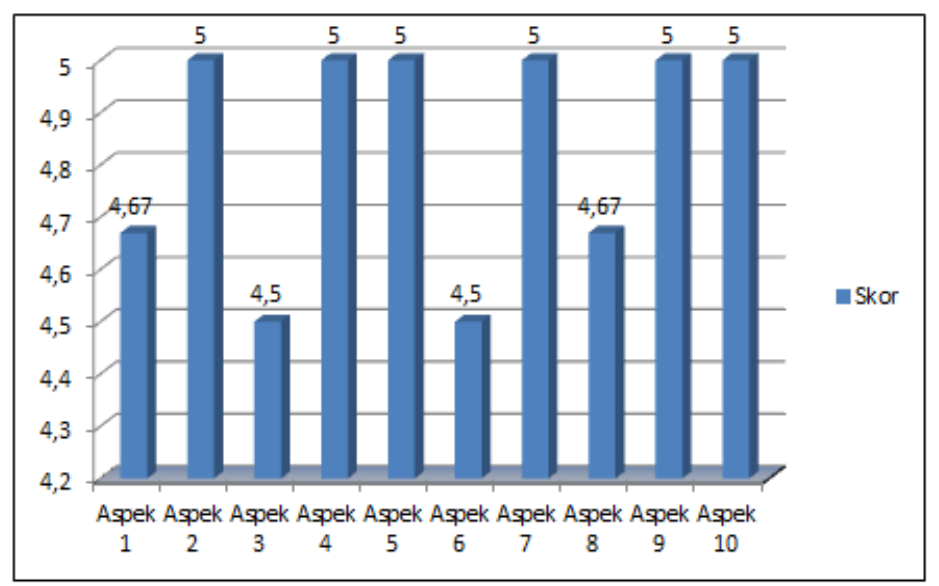

Gambar 3. Penilaian Guru 


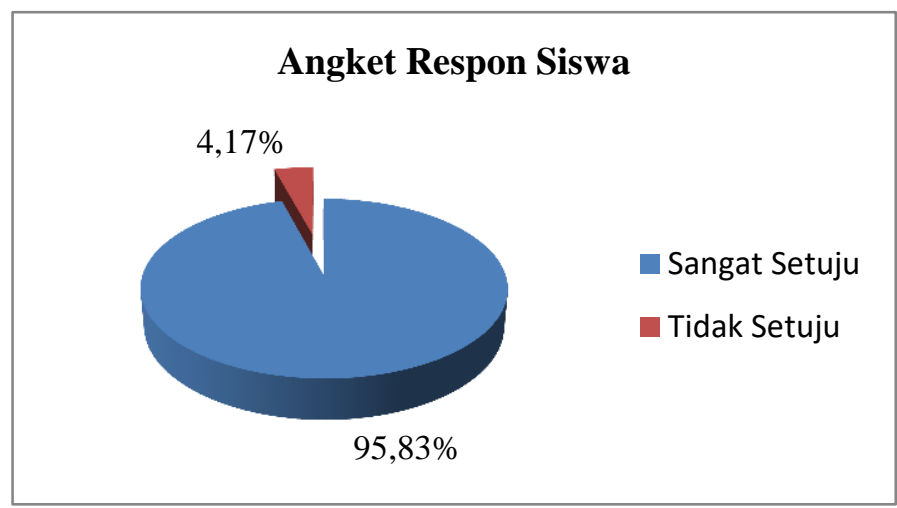

Gambar 4. Angket Respon Siswa

Kesimpulan dari perhitungan PRS menghasilkan 95,83\%, apabila dikonsultasikan pada tabel kriteria respon siswa dapat dinyatakan sangat setuju atau respon dinyatakan baik.

\section{SIMPULAN DAN SARAN}

Berdasarkan hasil penelitian dan pembahasan dapat disimpulkan bahwa : a) Data faktual di SD dalam penggunaan LKS matematika terdapat kelemahan yang harus ditangani dengan pengembangan LKS matematika, b) Pengembangan LKS matematika lambang bilangan romawi melalui strategi TANDUR merupakan alternatif yang dapat digunakan dalam menangani masalah yang ada di SD, c) Kevalidan terhadap LKS matematika lambang bilangan romawi melalui strategi TANDUR memperoleh skor rata-rata dari ketiga ahli sebesar 4,258, dan dikonsultasikan dengan tabel kriteria validasi LKS dinyatakan sangat valid, d) Uji hipotesis menyatakan bahwa LKS matematika lambang bilangan romawi melalui strategi TANDUR berpengaruh terhadap prestasi belajar matematika lambang bilangan romawi, e) Penilaian guru terhadap LKS matematika lambang bilangan romawi melalui strategi TANDUR memperoleh skor 4,834 dan dikonsultasikan dengan tabel penilaian guru dinyatakan sangat baik, f) Angket respon siswa terhadap LKS matematika lambang bilangan romawi melalui strategi TANDUR memperoleh presentase sebesar
95,83\% dan dikonsultasikan dengan tabel kriteria respon siswa dinyatakan sangat setuju dan respon siswa dinyatakan baik.

Saran dalam penelitian ini, antara lain : 1) Pemerolehan data faktual dapat diperluas dalam skala besar, sehingga diperoleh data lebih spesifik seperti pemilihan SD kota dan pedesaan, 2) Bila memungkinkan pengembangan dilakukan sampai tahap dessiminate, 3) Cakupan materi dapat diperluas dalam materi satu semester, karena seharusnya sebuah LKS tentunya dapat digunakan dalam satu semester, 4) Uji hipotesis terhadap LKS matematika lambang bilangan romawi melalui strategi TANDUR dapat diperluas sampai hasil belajar, karena pembelajaran tidak hanya menghasilkan prestasi belajar saja, tetapi sampai hasil belajar, 5) Uji coba dapat diperluas pada sekolah perkotaan dan pedesaan.

\section{DAFTAR PUSTAKA}

Deporter, Bobbi.dkk. 2014. Quantum Teaching. Bandung : Kaifa PT Mizan Pustaka

Hariwijaya. 2009. Meningkatkan Kecerdasan Matematika. Yogyakarta : Tugu Publisher.

Prastowo, Andi. 2014. Panduan Kreatif Membuat Bahan Ajar Inovatif. Yogyakarta : Diva Press

Tiagarajan, Sivasailam. dkk. 1974. Intructional Development for Trainging Teachers of Exceptional 
Children A Sourebook. Indiana : ERIC

Trianto. 2009. Mendesain Model Pembelajaran Inovatif-Progresif.

Jakarta : Kencana Prenada Media Group. 